\title{
Arachidonic Acid Plays a Role in Rat Vomeronasal Signal Transduction
}

\author{
Marc Spehr, Hanns Hatt, and Christian H. Wetzel \\ Department of Cell Physiology, Ruhr-University Bochum, 44780 Bochum, Germany
}

Sensory neurons of the vomeronasal organ (VNO) detect volatile chemicals that are released by conspecific animals and convey information about social and reproductive behavior. The signal transduction pathway in vomeronasal receptor neurons (VRNs) is not known in detail, but is believed to be distinct from that of the sensory neurons of the main olfactory system. Many of the identified olfactory transduction components are not expressed by VRNs. Using $\mathrm{Ca}^{2+}$ imaging and electrophysiological recordings, we investigated the signal transduction pathway of urine perception and the possible role of polyunsaturated fatty acids (PUFAs) as intracellular messengers in freshly dissociated rat VNO neurons. We found that application of urine induced a transient increase in intracellular $\mathrm{Ca}^{2+}$ that was dependent on the activity of phospholipase $\mathrm{C}$ and diacylglycerol (DAG) lipase. The $\mathrm{Ca}^{2+}$ transient was not dependent on depletion of intracellular
$\mathrm{Ca}^{2+}$ stores but was dependent on the presence of extracellular $\mathrm{Ca}^{2+}$. Furthermore, the urine response was not sensitive to modulators of adenylate cyclase and inhibitors of inositol 1,4,5trisphosphate receptors. Application of PUFAs (linolenic acid and arachidonic acid, synthesized in living cells from DAG) also elicited $\mathrm{Ca}^{2+}$ transients in fura 2 measurements and inward currents in whole-cell voltage-clamp recordings. Pharmacological inhibition of lipoxygenase and cyclooxygenase induced a transient increase in intracellular $\mathrm{Ca}^{2+}$, possibly by increasing the endogenous level of PUFAs, leading to activation of transduction channels. These data provide evidence for a role of PUFAs in rat vomeronasal signal transduction.

Key words: arachidonic acid; polyunsaturated fatty acids; PUFAs; signal transduction; calcium imaging; patch clamp; VNO; rat
The olfactory system has an exquisite capacity to discriminate among an immense variety of odorants that are present in the environment. In mammals, olfactory cues are detected by sensory neurons at two locations: the olfactory epithelium (OE) in the nasal cavity and the neuroepithelium of the vomeronasal organ (VNO). The VNO appears to detect predominantly but not exclusively pheromones that are emitted by other animals and convey information for social and reproductive behavior (Keverne, 1999; Pantages and Dulac, 2000; Sam et al., 2001).

In the VNO, the V1R and V2R families of candidate pheromone receptors are expressed by two spatially segregated populations of sensory neurons (Pantages and Dulac, 2000). Neurons lining the apical half of the neuroepithelium coexpress V1Rs as well as the G-protein $\alpha$ subunit $\mathrm{G}_{\alpha \mathrm{i} 2}$, whereas the basal neurons of the sensory epithelium are $\mathrm{V} 2 \mathrm{R}$ and $\mathrm{G}_{\alpha \mathrm{O}}$ positive (Berghard and Buck, 1996; Berghard et al., 1996).

Recently, it has already been shown that chemosensory function of the VNO neurons required phospholipase C (PLC), because pharmacological inhibition of PLC activity blocked the response of vomeronasal receptor neurons (VRNs) to urinary compounds (Berghard and Buck, 1996; Holy et al., 2000). It has also been shown that a member of the transient receptor potential (TRP) family of ion channels, TRP2, is expressed exclusively in the microvilli of VRNs and is likely to participate in the pheromone signal transduction cascade (Liman et al., 1999).

Arachidonic acid (AA) (20:4) is a cis-polyunsaturated fatty

Received April 24, 2002; revised June 13, 2002; accepted July 26, 2002.

This work was supported by the Deutsche Forschungsgemeinschaft (C.H.W., H.H.). We thank H. Bartel for technical assistance and Dr. B. W. Ache for comments on this manuscript.

Correspondence should be addressed to Dr. Christian H. Wetzel, Department of Cell Physiology, Ruhr-University Bochum, Universitaetsstrasse 150, 44780 Bochum, Germany. E-mail: christian.h.wetzel@ruhr-uni-bochum.de.

Copyright (ㄷ) 2002 Society for Neuroscience $0270-6474 / 02 / 228429-09 \$ 15.00 / 0$ acid ubiquitously present in the plasma membrane. It is normally linked covalently to other molecules in the membrane to form phospholipids but can be liberated by activation of cellular phospholipases. Unesterified, or free AA, has been shown to modulate the activity of various ion channels, including potassium (Kir, $\mathrm{BK}_{\mathrm{Ca}}$ ) or calcium $\left(\mathrm{I}_{\mathrm{ARC}}, \mathrm{TRP}\right)$ channels (Meves, 1994; Chyb et al., 1999; Mignen and Shuttleworth, 2000; Liu et al., 2001). AAdriven modulation can occur by both direct and indirect mechanisms. Many indirect effects are apparently mediated by AA metabolites (i.e., metabolic products of cyclooxygenase, lipoxygenase, or cytochrome P450-dependent epoxygenase) (Piomelli et al., 1987; Scherer and Breitwieser, 1990; Hu and Kim, 1993; Liu et al., 2001). Other indirect effects have been ascribed to activation of protein kinase C (PKC) (Keyser and Alger, 1990; Schmitt and Meves, 1993).

In rodents, the major source of pheromones seems to be urine; however, only a few volatile (Novotny et al., 1985) and nonvolatile (Vandenbergh et al., 1975) urinary substances producing a definite endocrine or behavioral response have been identified so far.

In the present study, we investigated the signal transduction pathway of pheromone (i.e., urinary compound) detection in rat VNO neurons by means of $\mathrm{Ca}^{2+}$ imaging and whole-cell voltageclamp recording. Using pharmacological blockers, we showed evidence for the contribution of putative signal transduction components [diacylglycerol (DAG) lipase and polyunsaturated fatty acids (PUFAs)] to the proposed pathway of pheromone detection and suggest an extended model for vomeronasal transduction.

\section{MATERIALS AND METHODS}

Tissue preparation. Male or female Wistar rats [postnatal day (P) 21-P56] were obtained from Charles River (Sulzfeld, Germany) and decapitated. The vomer bone capsule surrounding the VNO was dissected out and opened to gain access to the epithelia. The vomeronasal epithelium was dissected from the cartilage and placed in divalent cation-free papain 
solution (see Solutions). The vomeronasal epithelium was incubated in the enzyme solution for $20 \mathrm{~min}$ at room temperature and transferred to mammalian Ringer's solution (see Solutions) for gentle trituration with fire-polished Pasteur pipettes. Dissociated cells were subsequently filtered through a $70 \mu \mathrm{m}$ nylon cell strainer (Becton Dickinson) into fresh Ringer's solution in Concanavalin A-coated $35 \mathrm{~mm}$ Petri dishes and allowed to settle and attach.

$\mathrm{Ca}^{2+}$ imaging. The Ringer's solution was carefully drawn off the attached cells and replaced with the Ca-sensitive dye fura 2-AM (3 $\mu \mathrm{M})$ (Molecular Probes) in Ringer's solution. Cells were allowed to load for $30 \mathrm{~min}$ at room temperature before being washed with fura-free Ringer's solution for another $15 \mathrm{~min}$. The dish containing the cells was transferred to the stage of a Zeiss IM100 inverted microscope equipped for ratiometric imaging (Tillvision) and viewed with $32 \times$ magnification. All the cells in a field of view were illuminated every second for $50 \mathrm{msec}$ at 340 $\mathrm{nm}$ and $50 \mathrm{msec}$ at $380 \mathrm{~nm}$. The average pixel intensity within the user-selected regions of interest, corresponding to the individual cells, was digitized and stored on a PC. Cells that were clearly overloaded with dye were not included in the analysis. The $\mathrm{Ca}^{2+}$-dependent fluorescence signal at $510 \mathrm{~nm}$ was expressed as the F340/F380 ratio and viewed as a function of time.

Cells were exposed to urine or drugs, or both, using an application system that could transiently superfuse all the cells in the field of view from one of six user-selected capillary tubes. Switching time between test solutions essentially was instantaneous, as was the delay to onset after switching because of the close proximity of the tube tips to the optical field. A constant stream of mammalian Ringer's solution superfused all the cells in the dish between applications of test solutions to minimize any potential background accumulation of test solutions.

For each experimental paradigm, the presented data were obtained in at least three independent experiments using cells obtained from different preparations.

Electrophysiology. Freshly dissociated VRNs were voltage clamped at room temperature using whole-cell patch-clamp recording (Hamill et al., 1981) under visual control using an Axiovert 35M inverted microscope (Zeiss). Patch electrodes were pulled from borosilicate glass (Clark Electromedical Instruments, Pangbourne, UK) using a horizontal pipette puller (DMZ Universal Puller, Zeitz Instruments, Munich Germany) to yield pipettes with resistances of 3-6 M 2 . Pipettes were filled with an artificial intracellular solution (see Solutions). The liquid junction potential was estimated to $3 \mathrm{mV}$, and the membrane potential was not corrected. Voltage-clamp recordings and data acquisition were performed with an EPC-7 amplifier (List, Darmstadt, Germany), a Digidata 1200 interface, and the pCLAMP software running on a PC. Only neurons with seal resistances $R_{\mathrm{i}}>1 \mathrm{G} \Omega$ were used for the recordings. After the whole-cell configuration was established, the cell was lifted from the substrate and moved to the tip of a theta-tubing application device (Wetzel et al., 1998).

Solutions. Urine derived from individual male or female rats was collected on filter paper after gentle pressure of the animal's abdomen and stored at $-20^{\circ} \mathrm{C}$ until use. For use, a stock solution was produced by transferring the urine-saturated filter paper $\left(25 \mathrm{~cm}^{2}\right)$ to $25 \mathrm{ml}$ of Ringer's solution. This solution was diluted 1:1000 with Ringer's solution to working concentration, checked for $\mathrm{pH}$ and potassium concentration (no detectable change compared with Ringer's resulting from flame photometry). Solutions were filtered using disposable filter holders before use (0.22 $\mu \mathrm{m}$; Schleicher \& Schuell, Dassel, Germany).

Mammalian Ringer's solution consisted of (in mM): $138 \mathrm{NaCl}, 5 \mathrm{KCl}$, $2 \mathrm{CaCl}_{2}, 2 \mathrm{MgCl}_{2}, 10 \mathrm{HEPES}, 10$ glucose, adjusted to $\mathrm{pH} 7.4$ with $\mathrm{NaOH} . \mathrm{Ca}^{2+}$-free Ringer's solution contained (in $\mathrm{mM}$ ): $140 \mathrm{NaCl}, 5 \mathrm{KCl}$, $2 \mathrm{MgCl}_{2}, 5$ EGTA, 10 HEPES, 10 glucose, adjusted to $\mathrm{pH} 7.4$ with $\mathrm{NaOH}$. Divalent cation-free papain solution consisted of (in mM): 140 $\mathrm{NaCl}, 10$ HEPES, 10 glucose, $10 \mu \mathrm{g} / \mathrm{ml}$ papain, adjusted to $\mathrm{pH}$ 7.4. The patch pipette was filled with an artificial intracellular solution that consisted of (in mM): $140 \mathrm{KCl}, 1 \mathrm{MgCl}_{2}, 0.1 \mathrm{CaCl}_{2}, 10 \mathrm{HEPES}, 5$ EGTA, 2 ATP, adjusted to $\mathrm{pH} 7.4$ with $\mathrm{KOH}$.

All drugs were purchased from Calbiochem-Novabiochem (Bad Soden, Germany).

\section{RESULTS}

\section{VNO cells respond to urine with $\mathrm{Ca}^{2+}$ transients}

From a standard tissue preparation we obtained $\sim 30$ cells in each randomly selected field of view. Approximately $70 \%$ of these cells were regarded as neurons by their attached dendrite ending in a dendritic knob. Freshly dissociated VNO cells from male rats responded to application of urine (1: 1000; $5 \mathrm{sec}$ ) from male (2 of 89 cells) or female (5 of 89 cells) individuals with a transient increase in intracellular $\mathrm{Ca}^{2+}$. Similarly, 7 of $97 \mathrm{VNO}$ cells from female rats responded to application of male urine, and 4 of 97 responded to female urine $(1: 1000 ; 5 \mathrm{sec})$. Male urine stimulated a subset of neurons that was different from that stimulated by female urine. Only one neuron of a male VNO preparation responded to both male and female urine. We never observed an effect of urine from prepubertal rats on intracellular $\mathrm{Ca}^{2+}$ levels of male or female VNO cells (0 of 186). Using human urine as a further control, we found only one cell (1 of 186) responding to that stimulus, indicating that rat urine is an appropriate stimulus for rat VNO neurons. To investigate the signaling pathway of urine perception in an enlarged fraction of responding rat VNO neurons, we pooled dissociated cells from male and female VNOs and mixed urine samples from male and female individuals for use as urine stimulus.

Application of urine (1:1000) for $5 \mathrm{sec}$ to freshly dissociated VNO neurons induced a transient increase in intracellular $\mathrm{Ca}^{2+}$ in $8 \%$ of the cells (470 of 5872). Repeating the application of urine with an interstimulus interval of $\sim 60 \mathrm{sec}$ produced stimulus-correlated $\mathrm{Ca}^{2+}$ transients with nearly identical amplitudes in $82 \%$ of the responsive cells (Fig. 1). In $18 \%$ of the urine-responsive cells, the amplitudes decreased during repetitive stimulation. Reducing the interstimulus interval to $30 \mathrm{sec}$ increased the fraction of cells showing a further decrease in amplitudes of the corresponding urine stimulations, most likely reflecting an adaptation or desensitization process occurring in the transduction pathway.

Interestingly, dissociated neurons of the olfactory epithelium never responded to application of urine (1:1000) with an increase in intracellular $\mathrm{Ca}^{2+}$ (0 of 586 cells).

\section{The urine response is driven by extracellular $\mathrm{Ca}^{2+}$ and is independent of store depletion}

To investigate whether the urine response is dependent on extracellular $\mathrm{Ca}^{2+}$, we stimulated the VNO cells with urine dissolved in $\mathrm{Ca}^{2+}$-free Ringer's solution. In contrast to urine in $\mathrm{Ca}^{2+}$ containing Ringer's solution, application of urine under $\mathrm{Ca}^{2+}$. free conditions failed to induce $\mathrm{Ca}^{2+}$ signals in four of five cells. Subsequent application of urine in $\mathrm{Ca}^{2+}$ containing (normal) Ringer's solution again induced transient $\mathrm{Ca}^{2+}$ responses (Fig.

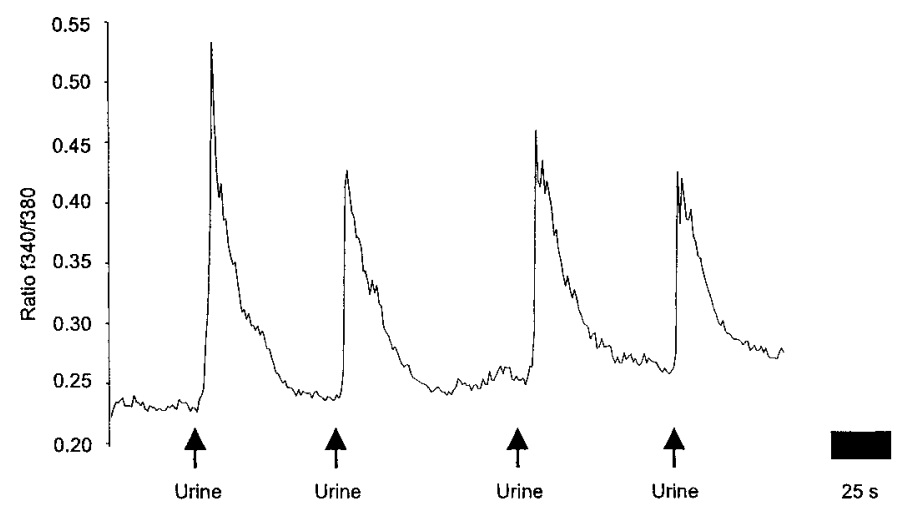

Figure 1. Repetitive application of urine (1:1000; duration $10 \mathrm{sec}$; indicated by the arrow) induced transient increases in intracellular $\mathrm{Ca}^{2+}$ in acutely dissociated rat VNR. Ordinate, Fluorescence ratio of fura 2-AM at 340 and $380 \mathrm{~nm}$. Time scale is $25 \mathrm{sec}(25 \mathrm{~s})$. 


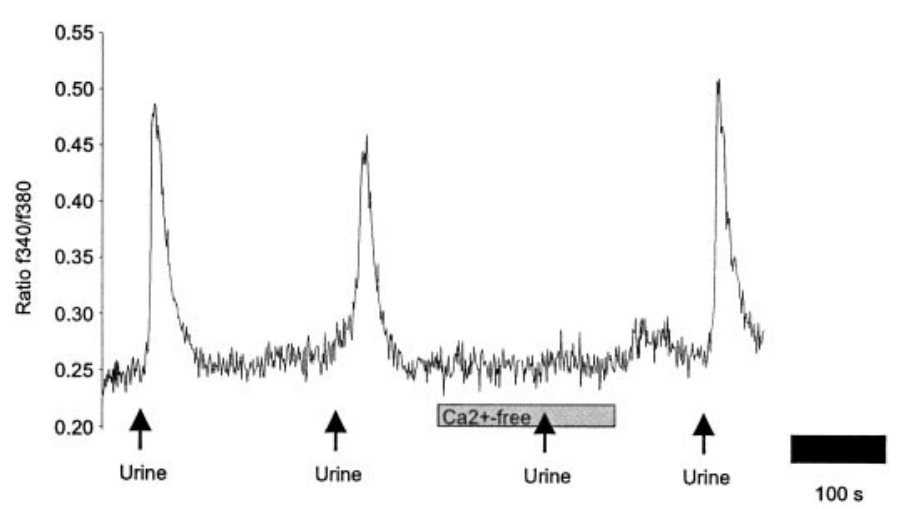

Figure 2. The urine-induced increase in intracellular $\mathrm{Ca}^{2+}$ was dependent on the presence of extracellular $\mathrm{Ca}^{2+}$. Note that the application of urine in $\mathrm{Ca}^{2+}$-free solution (gray bar) failed to induce $\mathrm{Ca}^{2+}$ transients in freshly dissociated rat VRNs. Ordinate, Fluorescence ratio of fura 2-AM at 340 and $380 \mathrm{~nm}$. Time scale is $100 \mathrm{sec}(100 \mathrm{~s})$.

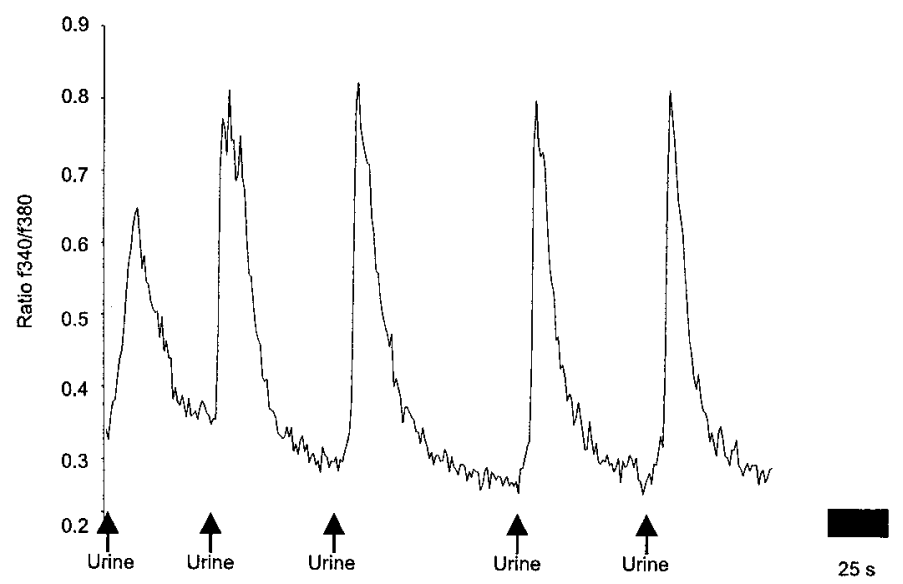

Figure 3. Urine-induced increase in intracellular $\mathrm{Ca}^{2+}$ was not dependent on intracellular stores. Preincubation of the cells with the SERCA inhibitor thapsigargin $(2 \mu \mathrm{M} ; 10 \mathrm{~min})$ had no effect on the urine response. Ordinate, Fluorescence ratio of fura 2-AM at 340 and $380 \mathrm{~nm}$. Time scale is $25 \mathrm{sec}(25 \mathrm{~s})$.

2). The dependence on outside $\mathrm{Ca}^{2+}$ is indicative of a cation permeable channel localized at the plasma membrane.

Application of the smooth endoplasmatic reticulum $\mathrm{Ca}^{2+}$ ATPase (SERCA) inhibitor thapsigargin $(2 \mu \mathrm{M})$ (Zufall et al., 2000) led to a prolonged increase in intracellular $\mathrm{Ca}^{2+}$ resulting from the depletion of internal stores. After $10 \mathrm{~min}$ incubation of the VNO cells in $2 \mu \mathrm{M}$ thapsigargin, the cells still were able to respond to urine stimulation. In detail, seven of seven VNO cells that showed a urine response before thapsigargin treatment also responded to urine after incubation with the SERCA inhibitor (Fig. 3). We conclude that the urine-induced increase in intracellular $\mathrm{Ca}^{2+}$ is not primarily dependent on intracellular $\mathrm{Ca}^{2+}$ stores.

\section{Adenylate cyclase is not involved in the urine-induced $\mathrm{Ca}^{2+}$ response}

In VNO neurons, adenylate cyclase (AC)(II) and AC(VI) are expressed in high levels (Berghard and Buck, 1996; Berghard et al., 1996; Rössler et al., 2000). To investigate the role of adenylate cyclases in the vomeronasal urine detection, we blocked a potential activity of AC by incubating the cells with the specific AC inhibitor MDL-12,330A (50 $\mu \mathrm{M} ; 70 \mathrm{sec})$ (Vogl et al., 2000). Cells

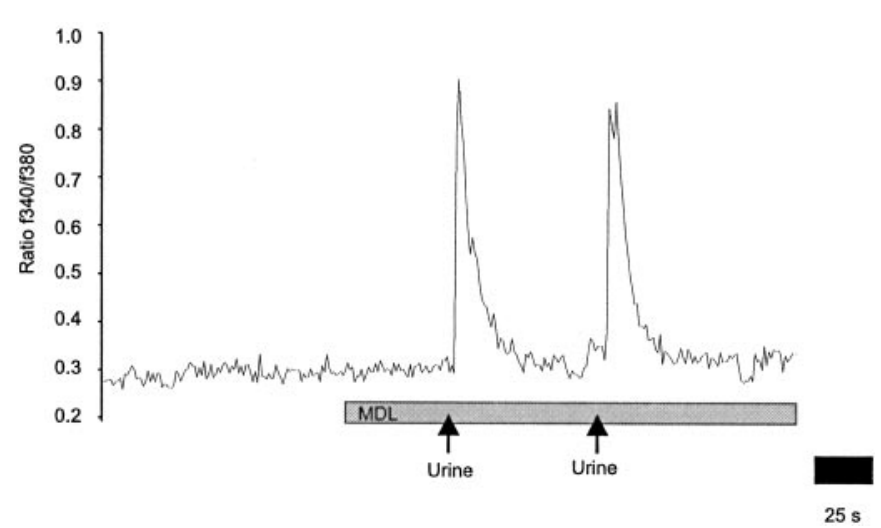

Figure 4. The adenylate cyclase inhibitor MDL-12,330A had no effect on the urine-induced $\mathrm{Ca}^{2+}$ response. Note that the amplitude of the $\mathrm{Ca}^{2+}$ transient was not changed in the presence of $50 \mu \mathrm{M}$ MDL-12,330A (gray bar). Ordinate, Fluorescence ratio of fura 2-AM at 340 and $380 \mathrm{~nm}$. Time scale is $25 \sec (25 s)$.

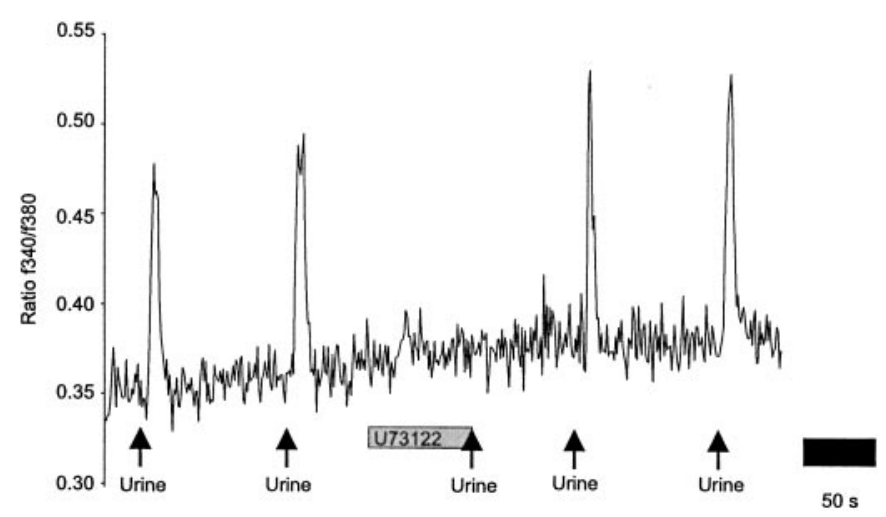

Figure 5. The PLC inhibitor U-73122 blocked the urine-induced $\mathrm{Ca}^{2+}$ response in freshly dissociated rat VRNs. Incubation with $50 \mu \mathrm{M} \mathrm{U}-73122$ (gray bar) prevented the cells from being activated by urine. Ordinate, Fluorescence ratio of fura 2-AM at 340 and $380 \mathrm{~nm}$. Time scale is $50 \mathrm{sec}$ $(50 s)$.

that responded to urine were not effected by MDL ( $n=3$ cells). The urine-induced increase of intracellular $\mathrm{Ca}^{2+}$ was in the same range before and in presence of MDL (Fig. 4). In contrast to VNO neurons, the odor response of olfactory receptor neurons (ORNs) in an equivalent experiment using a complex odorant and freshly dissociated rat olfactory tissue is highly sensitive to modulators of AC activity (data not shown).

Additionally, application of a potent activator of AC, forskolin $(100 \mu \mathrm{M})$, produced no $\mathrm{Ca}^{2+}$ signal in VRNs $(n=12$ cells; data not shown). This finding is in agreement with the assumption of different signal transduction pathways in the main olfactory epithelium and in the VNO (Berghard and Buck, 1996; Berghard et al., 1996; Dulac, 2000).

\section{The PLC inhibitor U-73122 blocks the urine response}

A key element in the proposed signal transduction pathway of vomeronasal pheromone detection is the enzyme PLC (Holy et al., 2000; Zufall and Munger, 2001). VNO cells that responded to urine application did not respond to urine after incubation with the specific PLC inhibitor U-73122 (50 $\mu \mathrm{M}$; incubation for $50 \mathrm{sec})$. Thus, U-73122 prevented all neurons that responded to urine before pharmacological treatment from producing a $\mathrm{Ca}^{2+}$ transient in response to urine $(n=5$ cells) (Fig. 5). Incubating the 


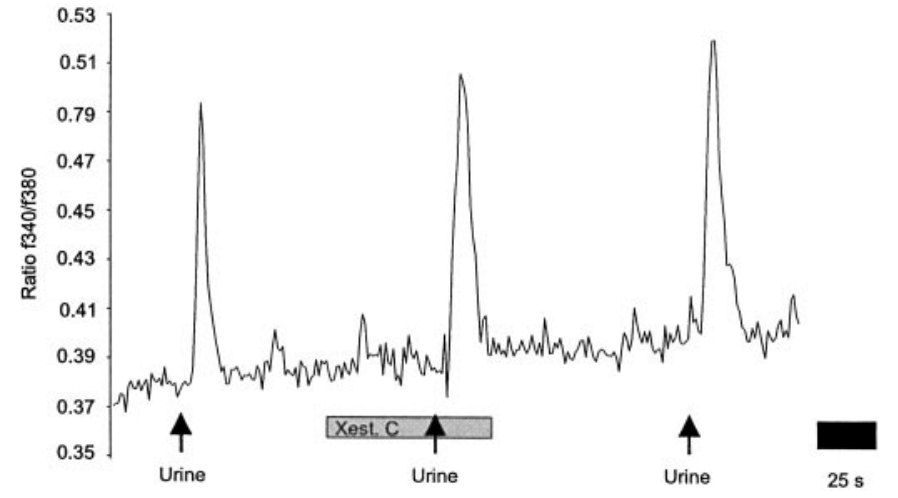

Figure 6. The $\mathrm{IP}_{3}$ receptor antagonist Xestospongin $\mathrm{C}$ had no effects on the urine-induced $\mathrm{Ca}^{2+}$ transients. Note that the amplitudes of the urine signals were not changed before, during, or after the application of (500 $\mathrm{nM}$ ) Xestospongin C (gray bar). Ordinate, Fluorescence ratio of fura 2-AM at 340 and $380 \mathrm{~nm}$. Time scale is $25 \mathrm{sec}(25 \mathrm{~s})$.

cells with U-73343, the analog of U-73122, acting as a very weak inhibitor of PLC, had no effect on the urine-induced $\mathrm{Ca}^{2+}$ signal ( $n=4$ cells; data not shown). These data show that PLC is involved in the signal transduction pathway of urine perception.

\section{IP3 receptor antagonists have no effect on urine- induced $\mathrm{Ca}^{2+}$ responses}

Our experiments clearly indicate that perception of urinary compounds in VRNs is PLC mediated. PLC catalyzes the hydrolysis of phosphatidylinositol 4,5 bisphosphate (PIP2) leading to $\mathrm{IP}_{3}$ and DAG. To investigate the impact of the metabolites on urine signal transduction, we tested the effect of a very potent, reversible, and membrane-permeable blocker of $\mathrm{IP}_{3}$-mediated $\mathrm{Ca}^{2+}$ release, Xestospongin C (500 nM) (Gafni et al., 1997) on the urine response of VNO neurons. We found that the urine-induced $\mathrm{Ca}^{2+}$ signal was not changed by Xestospongin $\mathrm{C}(n=6$ cells $)$ (Fig. 6). These experiments indicate that $\mathrm{IP}_{3}$ is not involved in the primary pathway of urine perception.

\section{Inhibitor of protein kinase $\mathbf{C}$ has no effect on the urine-induced $\mathrm{Ca}^{2+}$ signal}

After showing the involvement of PLC in urine perception, we tested for the contribution of PKC that is activated by diacylglycerol after stimulation of PLC (Bruch, 1996). We found that tamoxifen $(50 \mu \mathrm{M})$, an inhibitor of PKC had no detectable effect on the urine $\mathrm{Ca}^{2+}$ response of dissociated rat VRNs $(n=4$ cells), suggesting that $\mathrm{PKC}$ is not involved in primary urine perception (data not shown).

\section{An inhibitor of DAG lipase (RHC-80267) blocks the urine-induced $\mathrm{Ca}^{2+}$ signal}

Because pharmacological inhibition of $\mathrm{IP}_{3}$ receptors and $\mathrm{PKC}$ activity had no detectable effect on the urine $\mathrm{Ca}^{2+}$ response under our experimental conditions, we decided to investigate the possible role of DAG metabolites. In vivo, DAG can be metabolized to various PUFAs, e.g., arachidonic acid, by the activity of the enzyme DAG lipase (Meves, 1994). Interestingly, preincubation of VNO cells with $10 \mu \mathrm{M}$ RHC-80267, a specific inhibitor of DAG lipase, for 15-50 sec prevented seven cells that responded to urine before RHC-80267 treatment from being stimulated by urine application. The urine response recovered after $90 \mathrm{sec}$ of washout in $100 \%$ of the cells (Fig. 7). These results focused our interest on the putative impact of PUFAs on vomeronasal signal transduction.

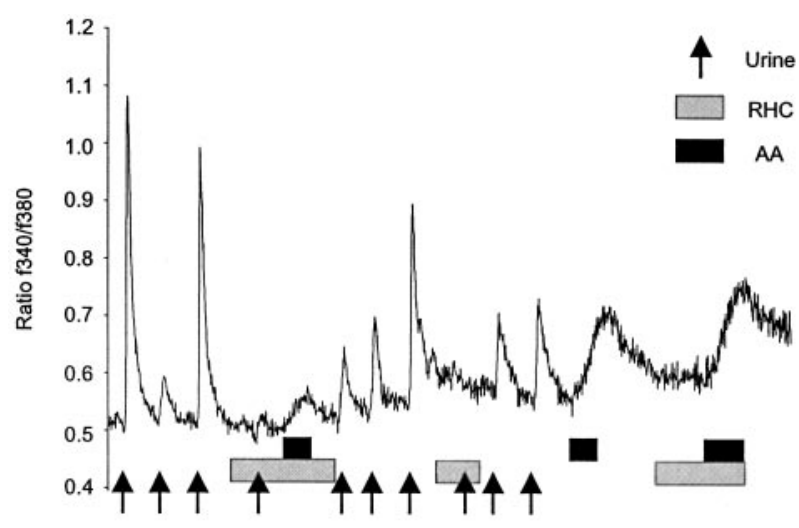

$100 \mathrm{~s}$

Figure 7. The DAG lipase inhibitor RHC-80267 blocked the urineinduced $\mathrm{Ca}^{2+}$ signal in acutely dissociated rat VRNs. Incubation of the cells with $10 \mu \mathrm{M}$ RHC-80267 inhibited the urine-induced $\mathrm{Ca}^{2+}$ response but had no effect on the AA-induced $\mathrm{Ca}^{2+}$ signal. Ordinate, Fluorescence ratio of fura 2-AM at 340 and $380 \mathrm{~nm}$. Time scale is $100 \mathrm{sec}(100 \mathrm{~s})$.

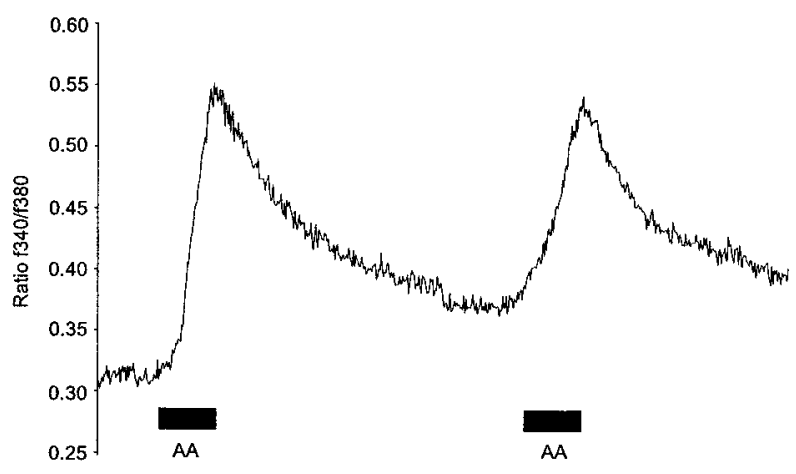

$50 \mathrm{~s}$

Figure 8. AA induced intracellular $\mathrm{Ca}^{2+}$ signals. Repetitive application of $50 \mu \mathrm{M}$ AA (black bar) induced transient increases in intracellular $\mathrm{Ca}^{2+}$ in acutely dissociated rat VRNs. Ordinate, Fluorescence ratio of fura $2-\mathrm{AM}$ at 340 and $380 \mathrm{~nm}$. Time scale is $50 \mathrm{sec}(50 \mathrm{~s})$.

\section{Arachidonic acid induces a transient increase in intracellular $\mathbf{C a}^{2+}$}

Interestingly, application of AA (50 $\mu \mathrm{M} ; 30-60 \mathrm{sec})$ induced a $\mathrm{Ca}^{2+}$ response in $56 \%$ of all cells in each randomly selected field of view (207 of 369). Compared with the urine response, which developed instantaneously after application of the urine stimulus, the AA response appeared with a delay of $\sim 25 \mathrm{sec}$ after start of AA application. The time course of the $\mathrm{Ca}^{2+}$ transient in response to AA was different from the kinetics of the urine response. Although the urine-induced intracellular $\mathrm{Ca}^{2+}$ signal reached a half-maximum value $\left(t_{50}\right)$ in $\sim 9 \mathrm{sec}$ after start of the urine application, the $\mathrm{Ca}^{2+}$ signal of the AA response had slower kinetics $\left(t_{50} \approx 70 \mathrm{sec}\right)$ (Fig. 8). Application of AA $(50 \mu \mathrm{M})$ never induced $\mathrm{Ca}^{2+}$ signals in freshly dissociated rat olfactory receptor neurons ( 0 of 70 cells), indicating that AA targets a VNO-specific process (data not shown).

\section{Linolenic acid induces a transient increase in intracellular $\mathrm{Ca}^{2+}$ in rat VRNs}

Linolenic acid, as well as arachidonic acid, produced by DAG lipase activity from diacylglycerol, is reported to activate the 


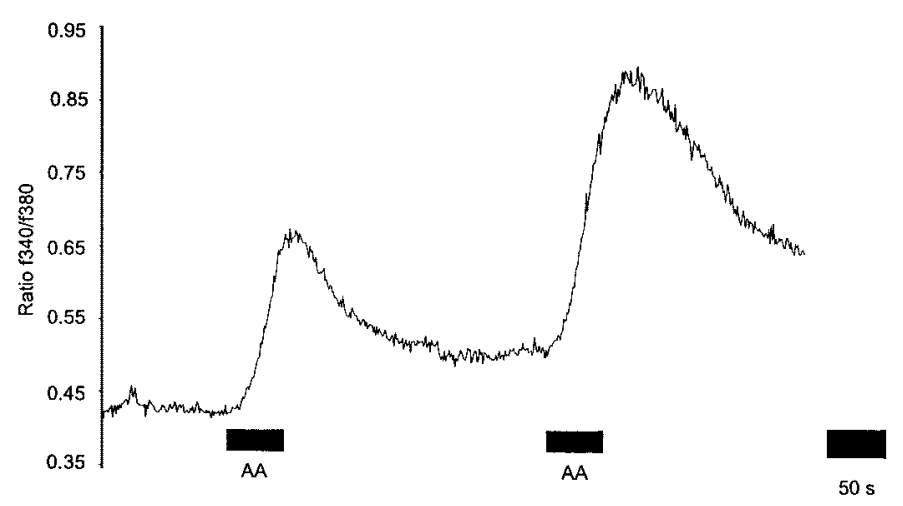

Figure 9. The AA-induced $\mathrm{Ca}^{2+}$ response is not dependent on intracellular $\mathrm{Ca}^{2+}$ stores. Note that depletion of the intracellular $\mathrm{Ca}^{2+}$ stores with the SERCA inhibitor thapsigargin $(10 \mu \mathrm{M})$ for $10 \mathrm{~min}$ could not prevent the AA-induced $\mathrm{Ca}^{2+}$ signal. Ordinate, Fluorescence ratio of fura 2-AM at 340 and $380 \mathrm{~nm}$. Application of $A A$ is indicated by black bars. Time scale is $50 \mathrm{sec}(50 \mathrm{~s})$.

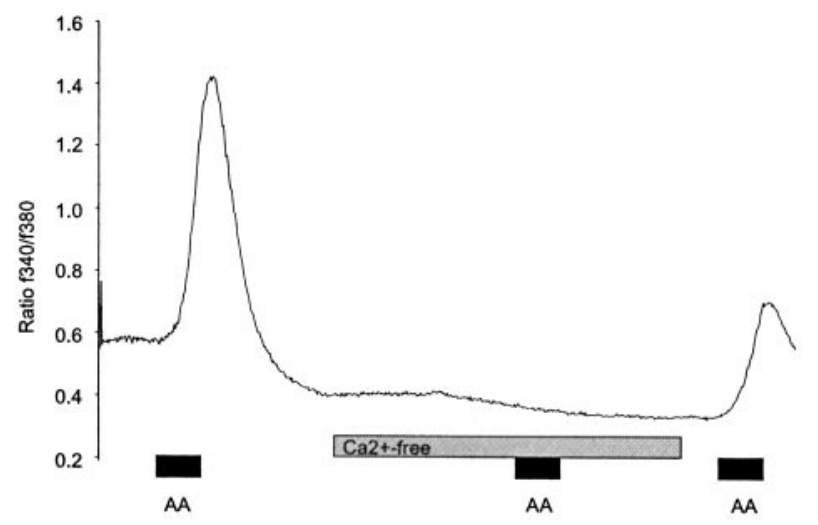

Figure 10. The AA-induced $\mathrm{Ca}^{2+}$ signal is dependent on extracellular $\mathrm{Ca}^{2+}$. Note that superfusion of the cells with $\mathrm{Ca}^{2+}$-free solution (gray bar) prevented cells that responded to AA $(50 \mu \mathrm{M})$ in $\mathrm{Ca}^{2+}$-containing solution from being activated by AA (black bar). Ordinate, Fluorescence ratio of fura 2-AM at 340 and $380 \mathrm{~nm}$. Time scale is $50 \mathrm{sec}(50 \mathrm{~s})$.

light-sensitive TRP and TRP-like (TRPL) channels in Drosophila, leading to a $\mathrm{Ca}^{2+}$ increase in Drosophila photoreceptor cells (Chyb et al., 1999). We tested for the effect of linolenic acid by applying $50 \mu \mathrm{M}$ to the freshly dissociated vomeronasal cell preparation. In five cells tested, $50 \mu \mathrm{M}$ linolenic acid evoked responses with amplitudes of $\sim 70 \%$ of the response induced by the same concentration of AA (data not shown).

\section{The arachidonic acid response is driven by extracellular $\mathrm{Ca}^{2+}$ and is independent of store depletion}

To investigate the underlying mechanisms, the cells were incubated for $10 \mathrm{~min}$ in the SERCA inhibitor thapsigargin $(10 \mu \mathrm{M})$. In three experiments, $100 \%$ of the cells that showed AA responses before thapsigargin treatment also responded to application of AA $(50 \mu \mathrm{M} ; 40-70 \mathrm{sec})$ after depletion of intracellular stores induced by thapsigargin treatment ( $n=7$ cells) (Fig. 9). This indicates that the $\mathrm{AA}$-induced $\mathrm{Ca}^{2+}$ signal is not dependent on intracellular $\mathrm{Ca}^{2+}$ stores. However, application of AA (50 $\mu \mathrm{M} ; 40$ sec) in $\mathrm{Ca}^{2+}$-free Ringer's solution failed to produce any $\mathrm{Ca}^{2+}$ signal in cells that responded to a control application of AA in the presence of $\mathrm{Ca}^{2+}\left(n=8\right.$ cells). In $100 \%$ of the cells, the $\mathrm{Ca}^{2+}$

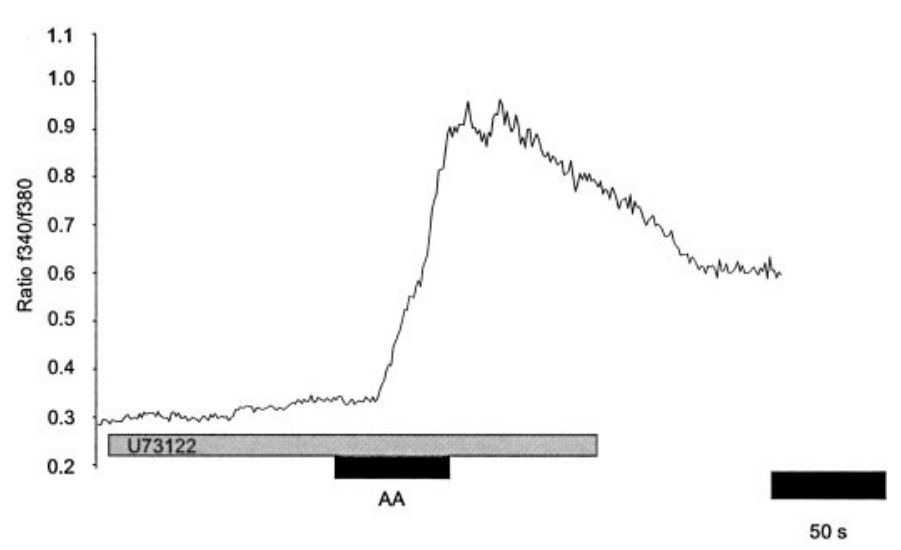

Figure 11. The AA response is not sensitive to the PLC inhibitor $\mathrm{U}-73122$. Note that preincubation of the cells with U-73122 (50 $\mu \mathrm{M})$ (gray bar) for $100 \mathrm{sec}$ did not prevent the cells from activation by AA $(50 \mu \mathrm{M})$ (black bar). Ordinate, Fluorescence ratio of fura 2-AM at 340 and $380 \mathrm{~nm}$. Time scale is $50 \mathrm{sec}(50 \mathrm{~s})$.

signal recovered qualitatively when AA again was delivered in $\mathrm{Ca}^{2+}$-containing Ringer's solution (Fig. 10). These data suggest that similar to the urine response of VNO cells, the response to AA is dependent on extracellular $\mathrm{Ca}^{2+}$ entering the cell through a yet unidentified ion channel.

\section{The arachidonic acid response is not sensitive to the PLC inhibitor U-73122}

To further investigate the involvement of putative signal transduction compounds, we tested the effect of the PLC inhibitor $\mathrm{U}-73122$ on the AA-induced $\mathrm{Ca}^{2+}$ signal. Preincubation of the VNO cells with $50 \mu \mathrm{M}$ U-73122 (20-100 sec), a protocol that was shown to inhibit the urine-induced $\mathrm{Ca}^{2+}$ signals (see above), had no effect on the AA response ( $n=6$ cells) (Fig. 11). This result is consistent with the hypothesis that AA signaling is located downstream of the PLC activity, and inhibition of PLC is without any effect on the action of AA on the activation of a particular $\mathrm{Ca}^{2+}$ channel.

\section{Pharmacological treatment of enzyme activity modulates the level of endogenous arachidonic acid}

Given that PUFAs (e.g., AA) play a major role in the vomeronasal urine perception, we investigated the effect of enzyme inhibitors presumed to modulate the level of endogenous PUFAs. The enzyme DAG lipase uses diacylglycerol as a substrate and catalyzes the synthesis of AA (Meves, 1994). In $100 \%$ of the cells ( 7 of 7), the DAG lipase inhibitor RHC-80267 blocked the urineinduced increase in intracellular $\mathrm{Ca}^{2+}$ but did not inhibit the $\mathrm{Ca}^{2+}$ signal induced by application of exogenous AA $(n=3$ cells) (Fig. 7). This indicates that DAG lipase is a major and essential component of the urine-perception pathway and that the $\mathrm{Ca}^{2+}$ signal can be restored by application of AA.

In living cells, inhibiting enzymes, which use AA as a substrate, can also modulate the endogenous AA signaling. Blocking the activity of the enzymes lipoxygenase and cyclooxygenase, which are known to metabolize AA (Piomelli et al., 1987; Scherer and Breitwieser, 1990; Hu and Kim, 1993), by application of nordihydroguaiaretic acid (NDGA), would therefore lead to an increase in concentration of endogenous AA in the cells. We found that in seven VRNs, application of $100 \mu \mathrm{M}$ NDGA led to a transient increase in intracellular $\mathrm{Ca}^{2+}$ (Fig. 12) and that the kinetics of the NDGA responses were similar to the kinetics of the AA-induced $\mathrm{Ca}^{2+}$ signals (compare Fig. 8). 


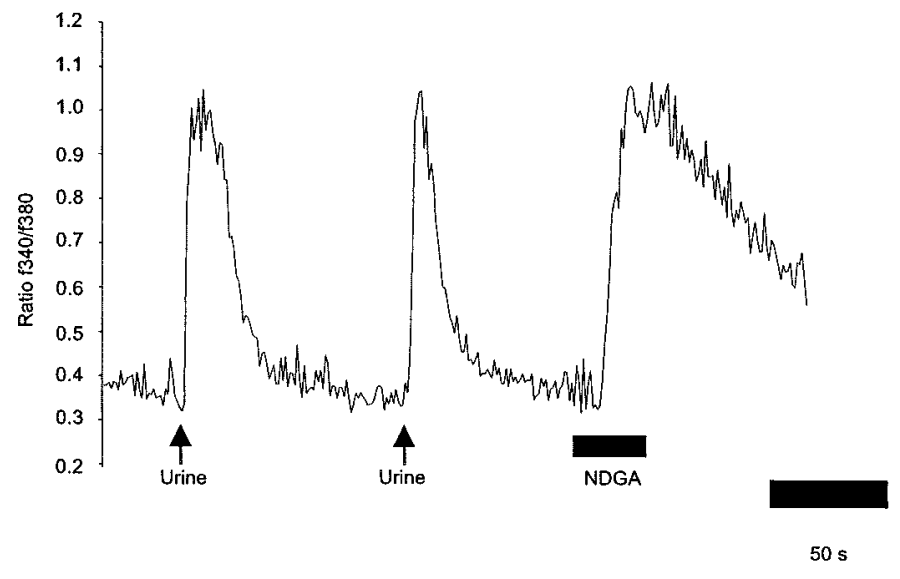

Figure 12. Application of the lipoxygenase and cyclooxygenase inhibitor NDGA $(100 \mu \mathrm{M})$ (black bar) produced a $\mathrm{Ca}^{2+}$ signal in acutely dissociated rat VRNs. Note that the $\mathrm{Ca}^{2+}$ transient was similar in amplitude to the urine-induced $\mathrm{Ca}^{2+}$ response. Ordinate, Fluorescence ratio of fura $2-\mathrm{AM}$ at 340 and $380 \mathrm{~nm}$. Time scale is $50 \mathrm{sec}(50 \mathrm{~s})$.

\section{Electrophysiology}

For electrophysiological investigation of the vomeronasal signal transduction pathway, we again used freshly dissociated rat VNO cells. Only cells with a long apical dendrite and a knob were regarded as neurons and used for whole-cell recordings. Testing the basic biophysical properties under current-clamp conditions revealed a mean zero current potential of $-62 \pm 12 \mathrm{mV}(n=54$ cells). Injection of $5 \mathrm{pA}$ positive current elicited repetitive action potentials in $92 \%$ of the neurons. In voltage-clamp recordings, applying voltage steps to potentials more positive than $-50 \mathrm{mV}$ induced fast sodium inward currents $\left(I_{\mathrm{Na}}\right)$ reaching a maximum amplitude of on average $1.7 \pm 0.2 \mathrm{nA}(n=22$ cells $)$ at a holding potential of $-20 \mathrm{mV}$. In addition, delayed rectifier potassium outward currents $\left(I_{\mathrm{K}(\mathrm{DR})}\right)$ developed at potentials more positive than $-40 \mathrm{mV}$ ( $n=23$ cells) (Fig. 13). These data indicate that the recorded VNO cells were healthy neurons (compare Liman and Corey, 1996).

The neuronal population of the rat VNO expresses 400 different types of putative pheromone receptors and is therefore expected to be highly diverse (Dulac, 2000). Individual VRNs show highly selective tuning properties (Leinders-Zufall et al., 2000), and the behaviorally effective pheromones found in urine have a mostly unknown chemical nature. Both facts contribute to the low frequency of urine-responsive cells identified in our $\mathrm{Ca}^{2+}$ imaging experiments. Therefore we decided to measure the effect of AA instead of urine on individual VRNs.

\section{Application of arachidonic acid induces inward currents}

Testing for the effect of AA on the dissociated VNO neurons, we applied $60 \mu \mathrm{M}$ AA for $90 \mathrm{sec}$ to cells voltage clamped at a potential of $-90 \mathrm{mV}$. After a latency of $\sim 10 \mathrm{sec}$, AA induced a slowly developing inward current and reached a peak amplitude of $-172 \pm 38 \mathrm{pA}$ after $\sim 45 \mathrm{sec}$ of application (11 of 12 cells) (Fig. 14). In contrast to VNO neurons, rat ORNs were not affected by application of $60 \mu \mathrm{M} \mathrm{AA}$ (0 of 9 cells), indicating that the observed effect on VNO neurons was caused by an interaction of AA with a VNO-specific ion channel or receptor.

\section{DISCUSSION}

In the present study, we investigated the signal transduction pathway of urine perception in freshly dissociated rat VRNs by
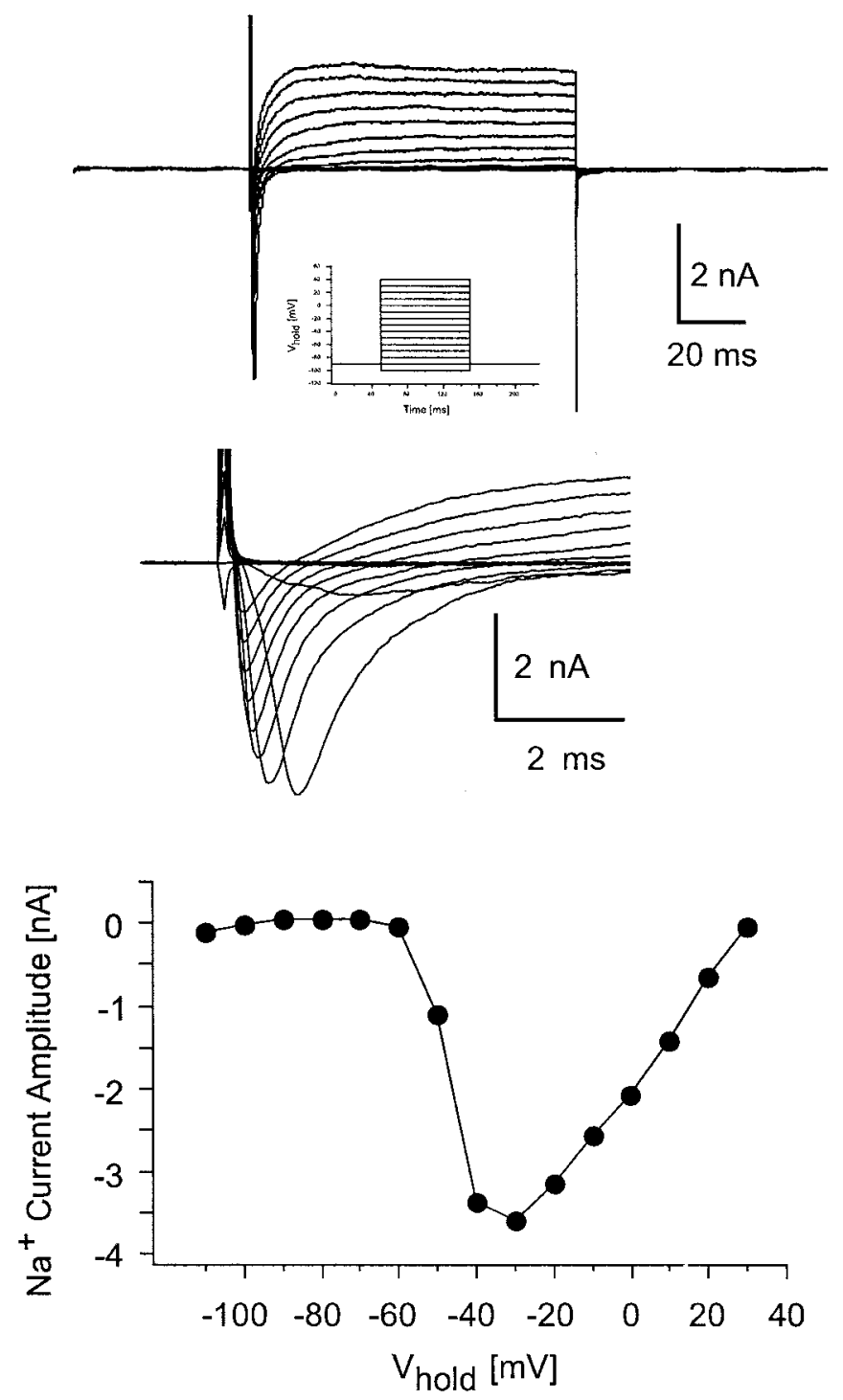

Figure 13. Whole-cell voltage-clamp recording of a freshly dissociated rat VRN. The voltage protocol is shown in the inset. Applying voltage steps to potentials more positive than $-50 \mathrm{mV}$ induced fast sodium inward currents $\left(I_{\mathrm{Na}}\right)$ reaching a maximum amplitude of on average $1.7 \pm$ $0.2 \mathrm{nA}(n=22$ cells $)$ at a holding potential of $-20 \mathrm{mV}$. Middle panel shows the fast sodium inward currents in another time scale. Delayed rectifier potassium outward currents $\left(I_{\mathrm{K}(\mathrm{DR})}\right)$ developed at potentials more positive than $-40 \pm 3 \mathrm{mV}(n=23$ cells $)$. Bottom panel shows the currentvoltage relationship of a representative VRN. Time scale is $2 \mathrm{msec}(2 \mathrm{~ms})$.

means of $\mathrm{Ca}^{2+}$ imaging. We showed that application of urine led to a transient increase of intracellular $\mathrm{Ca}^{2+}$. The signal transduction is PLC and DAG lipase dependent, because pharmacological inhibitors of these enzymes blocked the urine response. $\mathrm{Ca}^{2+}$ enters the cell from the extracellular compartment through an undefined ion channel. The $\mathrm{Ca}^{2+}$ signal is not sensitive to store depletion using thapsigargin. In addition, we found that PUFAs (AA or linolenic acid) are involved in vomeronasal signal transduction. AA induced $\mathrm{Ca}^{2+}$ responses that were not sensitive to inhibitors of PLC or DAG lipase. Increasing the endogenous level of AA by using the enzyme inhibitor NDGA induced $\mathrm{Ca}^{2+}$ responses in the absence of urine or exogenous AA. 


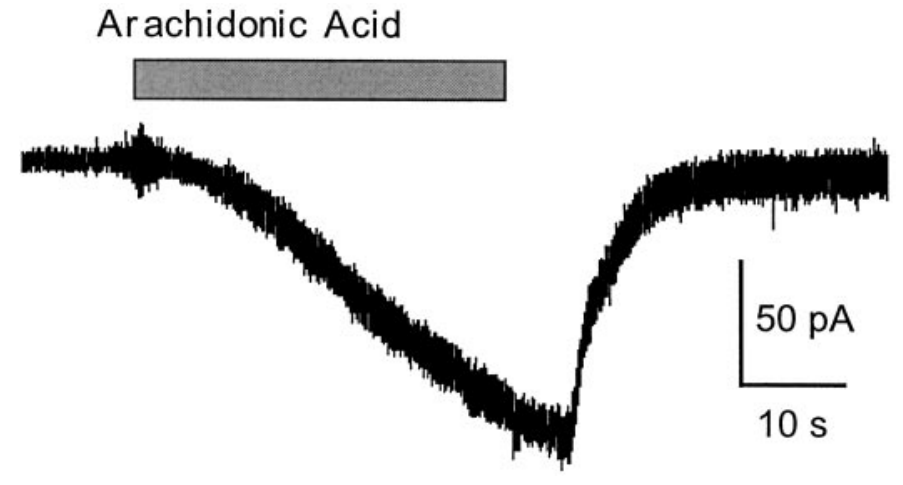

Figure 14. Application of AA induced inward currents in acutely dissociated rat VRNs. Membrane potential was held at $-90 \mathrm{mV}$. Application of $60 \mu \mathrm{M} \mathrm{AA}$ is indicated by the gray bar. The current developed slowly during the presence of AA and decayed after washout.

\section{AA is involved in vomeronasal signaling}

It has already been established that inhibition of the PLC blocked the response of VRNs of various species to urinary compounds (Holy et al., 2000; Leinders-Zufall et al., 2000). We found that pharmacological treatment of enzymes (DAG lipase, lipoxygenase, or cyclooxygenase) known to affect the metabolism and consequently the level of endogenous PUFAs, such as AA or linolenic acid, affected the $\mathrm{Ca}^{2+}$ signal, indicating that PUFAs play a role in vomeronasal urine perception. Blocking the activity of DAG lipase using the drug RHC-80267 inhibited the synthesis of PUFAs and prevented the VNO cells from being activated by urine. Additionally, the treatment of cyclooxygenase and lipoxygenase with the blocker NDGA inhibited the conversion of PUFAs to prostaglandins and leukotrienes, thereby increasing the level of endogenous PUFAs that subsequently produced a $\mathrm{Ca}^{2+}$ signal. These experiments strengthen the hypothesis that PUFAs (e.g., AA or linolenic acid) are involved in VNO signal transduction. However, we do not know explicitly whether linolenic acid, AA, or another related PUFA is the endogenous metabolite of the transduction pathway.

Application of AA to dissociated rat VRNs induced inward currents that were never observed by applying AA to dissociated rat ORNs. This indicates that AA activated a vomeronasalspecific ion channel or pathway that was not present in olfactory neurons.

The kinetics of the AA-induced signals differ from the kinetics of the urine responses. The time course of the AA response is similar to the kinetics of the AA-mediated effects reported for other ion channels (Meves, 1994; Liu et al., 2001). We believe that the activation of the transduction channels by AA is determined mainly by the diffusion rates of AA into the cell membranes and local interactions with the channel. However, the kinetics of the urine response may be dependent on the properties of the signal transduction pathway, including amplifying and regulatory processes in multimolecular signaling complexes (similar to transducisomes in the Drosophila eye) (Scott and Zuker, 1998). The kinetics of our recorded AA-induced inward currents resemble the course and time scale of the whole-cell currents induced by application of linolenic acid to Drosophila photoreceptor cells (Chyb et al., 1999), suggesting the possible involvement of a TRP or TRPL channel.

The difference in kinetics between urine and AA responses, however, could also provide some evidence for the existence of two separate but related and interdependent pathways that converge on a common molecular target (ion channel).

\section{TRP channels are candidate vomeronasal transduction channels}

Liman et al. (1999) reported the expression of rTRP2 exclusively in rat VNO neurons and showed that the protein is highly localized to VNO sensory microvilli, the proposed site of pheromone sensory transduction. Related to that, Stowers et al. (2002) and Leypold et al. (2002) showed that genetic ablation of TRP2 channel (TRP2-/- knock-out mice lacking the TRP2 channel) eliminates the sensory responses of VRNs to pheromonal cues present in urine, implying that the TRP2 conductance has an essential role in the transduction of pheromone signals. However, we could not identify the molecular type of $\mathrm{Ca}^{2+}$ channels activated by the transduction cascade in VNO sensory neurons, but the TRP2 channel is likely to be a good candidate for being the respective transduction channel.

Chyb et al. (1999) and Hofmann et al. (1999) demonstrated the direct activation of Drosophila TRP and TRPL ion channels and of human TRPC6 and TRPC3 channels by PUFAs (AA and linolenic acid) and diacylglycerol. Vannier et al. (1999) investigated the properties of mouse TRP2, the homolog of human TRPC2 pseudogene and the rTRP2, and reported that it encodes mTRP2, a store depletion-activated capacitative $\mathrm{Ca}^{2+}$ entry channel, when heterologously expressed in COS-M6 cells. We provide evidence for the absence of a mechanism involving store depletion. However, differences in activation properties of TRP channels are also reported for the TRPC1 (Zitt et al., 1996; Lintschinger et al., 2000) and might be attributable to experimental procedures, expression system (recombinant or native), or the coassemblence and interaction with other ion (or TRP) channels (Lintschinger et al., 2000; Strubing et al., 2001).

AA and other PUFAs affect many known ion channels, activating some and blocking others, often in concentrations as low as 1-10 $\mu \mathrm{M}$ (for review, see Meves, 1994). The mechanism by which AA affects ion channels is different for the different types of channels and includes direct effects on the channel protein or its lipid environment, activation of PKC or PLC, or activity of metabolites of AA. In the present study, we have shown some evidence that activation of PLC is upstream of the AA-induced calcium signal, whereas PKC activation seems not to be involved in urine-induced calcium increase. Detailed investigation of the mechanism of AA action in vomeronasal signal transduction will be a next important step.

Recently, Zhang et al. (2001) reported the activation of TRP3 channels by $\mathrm{IP}_{3}$ receptors through displacement of inhibitory calmodulin from a common binding site. Jungnickel et al. (2001) showed that TRP2 regulates the entry of $\mathrm{Ca}^{2+}$ into mouse sperm triggered by egg ZP3. This extracellular matrix component led to activation of PLC and a transient increase of intracellular $\mathrm{Ca}^{2+}$ caused by activation of $\mathrm{T}$-type $\mathrm{Ca}^{2+}$ channels. These early responses promote a second $\mathrm{Ca}^{2+}$ entry pathway that is dependent on TRP2. In our study, challenging the VNO cells with AA during whole-cell voltage-clamp recording prevented the contribution of voltage-activated ion channels. We suggest that the $\mathrm{Ca}^{2+}$ channels (i.e., transduction channels) are receptor activated and that the ligands are possibly PUFAs such as AA or linolenic acid. Striggow and Ehrlich (1997) have shown that AA inhibits the $\mathrm{IP}_{3}$ receptor located at the membranes of the endoplasmic reticulum, whereas its product leukotriene B4 (LTB4) stimulates the ryanodine receptor. We can exclude the involvement of LTB4 


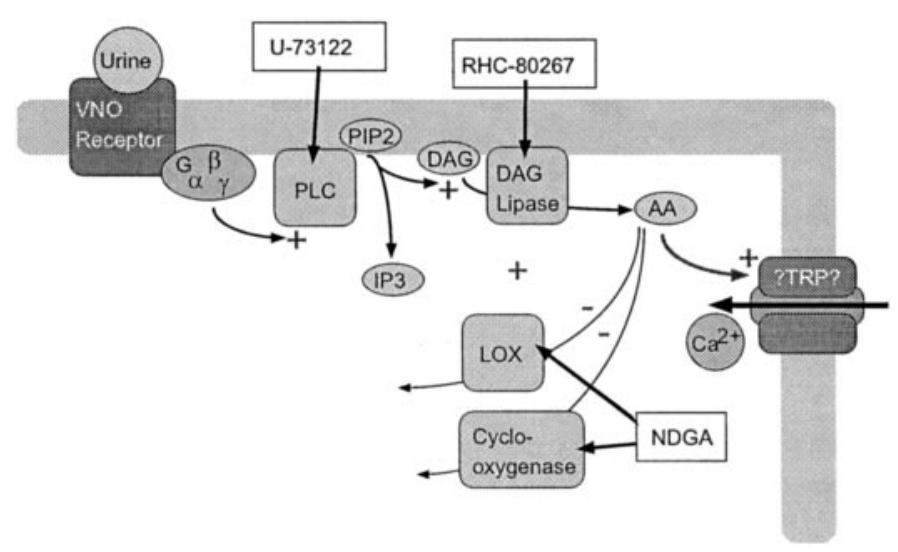

Figure 15. Scheme of the proposed signal transduction pathway of urine perception in rat VRNs. Urinary compounds are recognized by G-protein-coupled receptors that activate a PLC, which cleaves PIP2 resulting in $\mathrm{IP}_{3}$ and DAG. As a next step, AA is synthesized by the activity of DAG lipase and positively modulates a yet undefined ion channel that provides an inwardly directed calcium conductance. $G \alpha \beta \gamma$, Heterotrimeric G-protein; $L O X$, lipoxygenase.

in urine-induced calcium signaling by preventing the synthesis of LTB4 with the enzyme inhibitor NDGA.

\section{Adenylate cyclase is not involved in vomeronasal signaling}

In contrast to ORNs of the main olfactory epithelium, the $\mathrm{Ca}^{2+}$ level in VRNs is not sensitive to modulators of AC, a key enzyme in olfactory transduction (Schild and Restrepo, 1998). Neither stimulation of the AC by forskolin nor inhibition of the enzyme using MDL-12,330A affected the resting $\mathrm{Ca}^{2+}$ level of the unstimulated cells or the $\mathrm{Ca}^{2+}$ signal induced by urine or AA. These data are consistent with electrophysiological results from Taniguchi et al. (2000) on snake VRNs. They could not detect any current in response to intracellular application of $1 \mathrm{mM}$ cAMP.

Rössler et al. (2000) reported a decrease in intracellular cAMP in rat VRNs stimulated with urinary components. They conclude that the properties of cAMP signaling in the VNO of rats may be mediated by a $\mathrm{Ca}^{2+}$ - and protein kinase $\mathrm{C}$-inhibited $\mathrm{AC}(\mathrm{IV})$ subtype. In our study, blocking the protein kinase $\mathrm{C}$ by tamoxifen was without any effect on the urine-induced $\mathrm{Ca}^{2+}$ signal. However, these data do not exclude a possible modulation of cAMP signaling, which was not detectable in $\mathrm{Ca}^{2+}$ imaging.

\section{$\mathrm{IP}_{3}$ is not involved in vomeronasal perception of urinary compounds}

The involvement of the $\mathrm{IP}_{3}$ pathway is supported by the increase in $\mathrm{IP}_{3}$ levels elicited by vomeronasal stimuli in VRNs from hamsters, pigs, and garter snakes (Kroner et al., 1996; Wang et al., 1997; Wekesa and Anholt, 1997). In addition, using whole-cell voltage-clamp recordings, Inamura et al. (1997a) could show that $\mathrm{IP}_{3}$ that was injected into turtle or rat $\mathrm{VNO}$ cells led to an inward current, favoring the idea that $\mathrm{IP}_{3}$ is involved in VNO signal transduction. Inamura et al. (1997a,b) reported the block of urinary responses by inhibitors for the $\mathrm{IP}_{3}$-mediated pathway (10 $\mu \mathrm{M}$ ruthenium red) in rat VRNs. We tested for the contribution of $\mathrm{IP}_{3}$ and $\mathrm{IP}_{3}$ receptors to the urine-induced $\mathrm{Ca}^{2+}$ signal by using the potent and membrane-permeable $\mathrm{IP}_{3}$ receptor antagonist Xestospongin C. Because this blocker had no effect on the urine-induced $\mathrm{Ca}^{2+}$ signal, we concluded that $\mathrm{IP}_{3} / \mathrm{IP}_{3}$ receptors are not directly involved in urine perception. The signaling cascade involved in the chemosensory transduction in the snake
$\mathrm{VNO}$ is likely to be dependent on $\mathrm{IP}_{3}$ production (Taniguchi et al., 2000; Cinelli et al., 2002). In this system, two parallel $\mathrm{IP}_{3^{-}}$ sensitive pathways lead to a transient increase in intracellular $\mathrm{Ca}^{2+}$ in the dendritic region of snake vomeronasal neurons: $\mathrm{Ca}^{2+}$ influx through the plasma membrane and a $\mathrm{Ca}^{2+}$ release from intracellular stores (Cinelli et al., 2002); however, we cannot exclude the possibility that $\mathrm{IP}_{3}$ and its receptors play a modulatory role in rat $\mathrm{VNO}$ neurons.

\section{Summary}

In summary, we investigated the signal transduction pathway of urine perception in freshly dissociated rat VRNs. We reported the involvement of PLC and DAG lipase in signal transduction and showed the contribution of PUFAs, such as linolenic acid or AA. We showed that the $\mathrm{Ca}^{2+}$ signals are independent from intracellular stores and that $\mathrm{Ca}^{2+}$ enters the cell from the extracellular compartment. The molecular nature of the $\mathrm{Ca}^{2+}$ conductance remains to be established in future work. A scheme of the proposed signal transduction pathway is depicted in Figure 15.

\section{REFERENCES}

Berghard A, Buck LB (1996) Sensory transduction in vomeronasal neurons: evidence for $\mathrm{G} \alpha \mathrm{o}, \mathrm{G} \alpha \mathrm{i} 2$, and adenylyl cyclase II as major components of a pheromone signaling cascade. J Neurosci 16:909-918.

Berghard A, Buck LB, Liman ER (1996) Evidence for distinct signaling mechanisms in two mammalian olfactory sense organs. Proc Natl Acad Sci USA 93:2365-2369.

Bruch RC (1996) Phosphoinositide second messengers in olfaction. Comp Biochem Physiol B Biochem Mol Biol 113:451-459.

Chyb S, Raghu P, Hardie RC (1999) Polyunsaturated fatty acids activate the Drosophila light-sensitive channels TRP and TRPL. Nature 397:255-259.

Cinelli AR, Wang D, Chen P, Liu W, Halpern M (2002) Calcium transients in the garter snake vomeronasal organ. J Neurophysiol 87:1449-1472.

Dulac C (2000) Sensory coding of pheromone signals in mammals. Curr Opin Neurobiol 10:511-518.

Gafni J, Munsch JA, Lam TH, Catlin MC, Costa LG, Molinski TF, Pessah IN (1997) Xestospongins: potent membrane permeable blockers of the inositol 1,4,5-trisphosphate receptor. Neuron 19:723-733.

Hamill OP, Marty A, Neher E, Sakmann B, Sigworth FJ (1981) Improved patch-clamp techniques for high-resolution current recording from cells and cell-free membrane patches. Pflügers Arch 391:85-100

Hofmann T, Obukhov AG, Schaefer M, Harteneck C, Gudermann T, Schultz G (1999) Direct activation of human TRPC6 and TRPC3 channels by diacylglycerol. Nature 397:259-263.

Holy TE, Dulac C, Meister M (2000) Responses of vomeronasal neurons to natural stimuli. Science 289:1569-1572.

$\mathrm{Hu}$ S, Kim HS (1993) Activation of $\mathrm{K}^{+}$channel in vascular smooth muscles by cytochrome P450 metabolites of arachidonic acid. Eur J Pharmacol 230:215-221.

Inamura K, Kashiwayanagi M, Kurihara K (1997a) Inositol-1,4,5trisphosphate induces responses in receptor neurons in rat vomeronasal sensory slices. Chem Senses 22:93-103.

Inamura K, Kashiwayanagi M, Kurihara K (1997b) Blockage of urinary responses by inhibitors for IP3-mediated pathway in rat vomeronasa sensory neurons. Neurosci Lett 233:129-132.

Jungnickel MK, Marrero H, Birnbaumer L, Lemos JR, Florman HM (2001) Trp2 regulates entry of $\mathrm{Ca}^{2+}$ into mouse sperm triggered by egg ZP3. Nat Cell Biol 3:499-502.

Keverne EB (1999) The vomeronasal organ. Science 286:716-720.

Keyser DO, Alger BE (1990) Arachidonic acid modulates hippocampal calcium current via protein kinase $\mathrm{C}$ and oxygen radicals. Neuron 5:545-553.

Kroner C, Breer H, Singer AG, O'Connell RJ (1996) Pheromoneinduced second messenger signaling in the hamster vomeronasal organ. NeuroReport 7:2989-2992.

Leinders-Zufall T, Lane AP, Puche AC, Ma W, Novotny MV, Shipley MT, Zufall F (2000) Ultrasensitive pheromone detection by mammalian vomeronasal neurons. Nature 405:792-796.

Leypold BG, Yu CR, Leinders-Zufall T, Kim MM, Zufall F, Axel R (2002) Altered sexual and social behaviors in trp2 mutant mice. Proc Natl Acad Sci USA 99:6376-6381.

Liman ER, Corey DP (1996) Electrophysiological characterization of chemosensory neurons from the mouse vomeronasal organ. J Neurosci 16:4625-4637.

Liman ER, Corey DP, Dulac C (1999) TRP2: a candidate transduction 
channel for mammalian pheromone sensory signaling. Proc Natl Acad Sci USA 96:5791-5796.

Lintschinger B, Balzer-Geldsetzer M, Baskaran T, Graier WF, Romanin C, Zhu MX, Groschner K (2000) Coassembly of Trp1 and Trp3 proteins generates diacylglycerol- and $\mathrm{Ca}^{2+}$-sensitive cation channels. J Biol Chem 275:27799-27805.

Liu Y, Liu D, Heath L, Meyers DM, Krafte DS, Wagoner PK, Silvia CP, Yu W, Curran ME (2001) Direct activation of an inwardly rectifying potassium channel by arachidonic acid. Mol Pharmacol 59:1061-1068.

Meves H (1994) Modulation of ion channels by arachidonic acid. Prog Neurobiol 43:175-186.

Mignen O, Shuttleworth TJ (2000) I(ARC), a novel arachidonateregulated, noncapacitative $\mathrm{Ca}(2+)$ entry channel. J Biol Chem 275:9114-9119.

Novotny M, Harvey S, Jemiolo B, Alberts J (1985) Synthetic pheromones that promote inter-male aggression in mice. Proc Natl Acad Sci USA 82:2059-2061.

Pantages E, Dulac C (2000) A novel family of candidate pheromone receptors in mammals. Neuron 28:835-845.

Piomelli D, Shapiro E, Feinmark SJ, Schwartz JH (1987) Metabolites of arachidonic acid in the nervous system of Aplysia: possible mediators of synaptic modulation. J Neurosci 7:3675-3686.

Rössler P, Kroner C, Krieger J, Lobel D, Breer H, Boekhoff I (2000) Cyclic adenosine monophosphate signaling in the rat vomeronasal organ: role of an adenylyl cyclase type VI. Chem Senses 25:313-322.

Sam M, Vora S, Malnic B, Ma W, Novotny MV, Buck LB (2001) Neuropharmacology. Odorants may arouse instinctive behaviours. Nature 412:142.

Scherer RW, Breitwieser GE (1990) Arachidonic acid metabolites alter $\mathrm{G}$ protein-mediated signal transduction in heart. Effects on muscarinic $\mathrm{K}+$ channels. J Gen Physiol 96:735-755.

Schild D, Restrepo D (1998) Transduction mechanisms in vertebrate olfactory receptor cells. Physiol Rev 78:429-466.

Schmitt H, Meves H (1993) Protein kinase C as mediator of arachidonic acid-induced decrease of neuronal $M$ current. Pflügers Arch 425:134-139.

Scott K, Zuker CS (1998) Assembly of the Drosophila phototransduction cascade into a signalling complex shapes elementary responses. Nature 395:805-808.

Stowers L, Holy TE, Meister M, Dulac C, Koentges G (2002) Loss of sex discrimination and male-male aggression in mice deficient for trp2. Science 295:5559.
Striggow F, Ehrlich BE (1997) Regulation of intracellular calcium release channel function by arachidonic acid and leukotriene B4. Biochem Biophys Res Commun 237:413-418.

Strubing C, Krapivinsky G, Krapivinsky L, Clapham DE (2001) TRPC1 and TRPC5 form a novel cation channel in mammalian brain. Neuron 29:645-655.

Taniguchi M, Wang D, Halpern M (2000) Chemosensitive conductance and inositol 1,4,5-trisphosphate-induced conductance in snake vomeronasal receptor neurons. Chem Senses 25:67-76.

Vandenbergh JG, Whitsett JM, Lombardi JR (1975) Partial isolation of a pheromone accelerating puberty in female mice. J Reprod Fertil 43:515-523.

Vannier B, Peyton M, Boulay G, Brown D, Qin N, Jiang M, Zhu X, Birnbaumer L (1999) Mouse trp2, the homologue of the human trpc2 pseudogene, encodes mTrp2, a store depletion-activated capacitative $\mathrm{Ca}^{2+}$ entry channel. Proc Natl Acad Sci USA 96:2060-2064.

Vogl A, Noe J, Breer H, Boekhoff I (2000) Cross-talk between olfactory second messenger pathways. Eur J Biochem 267:4529-4535.

Wang D, Chen P, Liu W, Li CS, Halpern M (1997) Chemosignal transduction in the vomeronasal organ of garter snakes: $\mathrm{Ca}(2+)$-dependent regulation of adenylate cyclase. Arch Biochem Biophys 348:96-106.

Wekesa KS, Anholt RR (1997) Pheromone regulated production of inositol-(1,4,5)-trisphosphate in the mammalian vomeronasal organ. Endocrinology 138:3497-3504.

Wetzel CH, Hermann B, Behl C, Pestel E, Rammes G, Zieglgansberger W, Holsboer F, Rupprecht R (1998) Functional antagonism of gonadal steroids at the 5-hydroxytryptamine type 3 receptor. Mol Endocrinol 12:1441-1451.

Zhang J, Yuliang M, Taylor SS, Tsien RY (2001) Genetically encoded receptors of protein kinase A activity reveal impact of substrate tethering. Proc Natl Acad Sci USA 98:14997-15002.

Zitt C, Zobel A, Obukhof AG, Harteneck C, Kalkbrenner F, Luckhoff A Schultz G (1996) Cloning and functional expression of a human $\mathrm{Ca}^{2+}$-permeable cation channel activated by calcium store depletion. Neuron 16:1189-1196.

Zufall F, Munger SD (2001) From odor and pheromone transduction to the organization of the sense of smell. Trends Neurosci 24:191-193.

Zufall F, Leinders-Zufall T, Greer CA (2000) Amplification of odorinduced $\mathrm{Ca}(2+)$ transients by store-operated $\mathrm{Ca}(2+)$ release and its role in olfactory signal transduction. J Neurophysiol 83:501-512. 